\title{
Prevalence of wheeze among preschool children in Basra governonate, southern Iraq
}

M.B. Salem, ${ }^{1}$ I.O. Al-Sadoon' and M.K. Hassan'

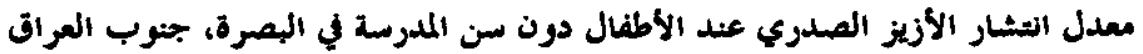

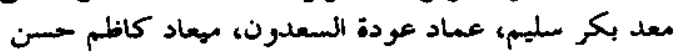

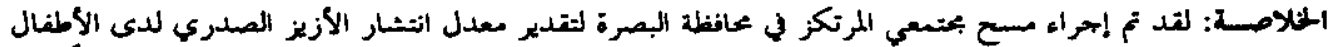

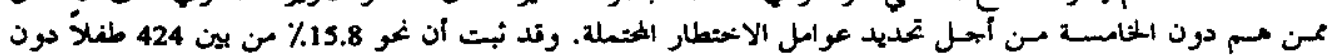

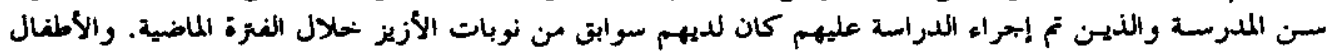

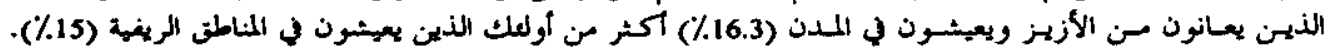

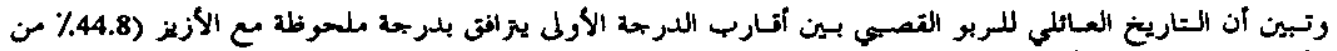

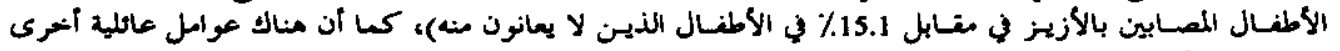

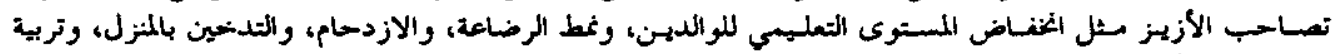

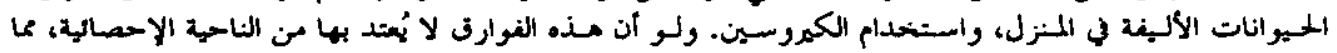

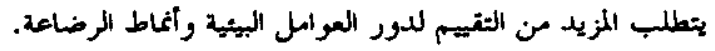

ABSTRACT A community-based survey was carried out in Basra governorate, Iraq, to estimate the prevalence of wheeze among children under 5 years old and to identify possible risk factors. It was found that

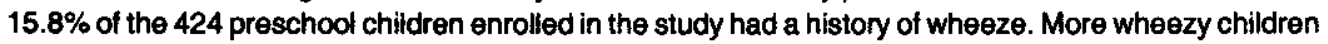
lived in the city (16.3\%) than in the rural area (15.0\%). Family history of asthma in first-degree relatives was significantly associated with wheeze ( $44.8 \%$ of children with wheeze versus $15.1 \%$ without wheeze). Other household factors - parents' low educational level, formula or supplemental feeding as a baby, overcrowding, smoking at home, pet ownership and using kerosene - were associated with wheeze, but the results were not statistically significant. The role of environmental factors and feeding patterns needs to be further ovaluated.

Prévalence de la respiration sifflante chez les enfants d'âge préscolaire dans le Gouvernorat de Bassora au sud de l'iraq

RESUME Une enquéte communautaire a été réalisée dans le Gouvernorat de Bassora (Iraq) pour estimer la prévalence de la respiration sifflante chez les enfants de moins de cinq ans et identifier les facteurs de risque éventuels. On a constaté que 15,8\% des 424 enfants d'áge préscolaire admis dans l'étude avaient des antécédents de respiration sifflante. Les enfants ayant une respiration sifflante étaient en plus grand nombre en zone urbaine $(16,3 \%)$ qu'en zone rurale $(15,0 \%)$. Les antécédents familiaux d'asthme chez les parents du premier degré étaient significativement associés à la respiration siffiante $(44,8 \%$ des enfants ayant une respiration sifflante contre $15,1 \%$ sans respiration sifflante). D'autres facteurs liés au foyer - faible niveau d'instruction des parents, allaitement artificiel pendant la petite enfance, promiscuité, tabagisme à la maison, possession d'un animal familier et utilisation de pétrole-étaient associés à la respiration sifflante, mais les résultats n'étaient pas statistiquement significatifis. Le rôle des facteurs liés à l'environnement et des modes d゙alimentation doit faire l'objet d̛une évaluation plus pousséé.

'Department of Paediatrics, College of Medicine, University of Basra, Basra, Iraq. Received: 11/01/01; accepted: 09/04/02

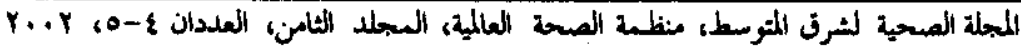




\section{Introduction}

Recurrent wheezing among preschool children is a common problem that generates much parental concern and is associated with frequent visits to medical and paediatric casualty departments [1-4]. Until recently, the earliest stages of asthma in young children have not been investigated in detail and there has been controversy over the nature of recurrent wheezing following viral respiratory infection $[5,6]$. These attacks were sometimes labelled as wheezy baby syndrome or episodic wheeze syndrome $[4,5]$. Luyt et al. reported that $15.6 \%$ of preschool children in Britain have wheezed and $80 \%$ of these children have recurrent episodes [1]. The Martinez cohort study [5] showed that $19.9 \%$ of children had had one attack of wheeze before the age of 3 years old; this group had diminished airway function at birth and showed a transient condition not associated with family atopy, elevated immunoglobulin $\mathrm{E}$ (IgE) levels or maternal smoking. On the other hand, $13.7 \%$ of the children had recurrent attacks of wheeze between 3 and 6 years of age. These were mostly from atopic families and were more likely to develop childhood asthma [5]. These results are in agreement with Luyt et al.'s conclusion that recurrent wheezing is not related to colds and suggests the likelihood of asthma [1].

The etiology of wheezing in preschool children has also received much attention [5-7]. Although Horwood et al. did not classify wheezing episodes according to age of onset, they found an association with family atopy, especially asthma, but not with a large number of environmental and social factors. In contrast, other studies found a close association between early wheezing episodes and maternal smoking $[5,8]$.
The aim of the present study in southern Iraq was to estimate the prevalence of recurrent wheezing among preschool children at a community level and to identify possible risk factors.

\section{Methods}

This community-based survey was carried out during March to April 2001in three areas in the Basra governorate of Iraq: one rural area $3 \mathrm{~km}$ from Basra city centre and two city centre areas. All the families in the area were visited and standard questionnaires were completed by the researchers based on parental accounts of symptoms in their children. All children under 5 years and over 2 months of age in the areas were included in the study.

The questionnaire aimed to identify and describe wheeze among the children by asking: if the child had ever had attacks of wheezing; the number of attacks in the past 12 months; whether attacks cause him/her to be short of breath; whether attacks occur when the child has a cold, when playing or running or near animals, dust or grass, etc; and whether the father, mother or siblings has ever suffered from asthma, eczema or hay fever. Wheezing was defined for parents as: 'a high pitched musical or whistling sound coming from the chest during breathing, not from the throat'.

Parents also answered questions about: child's age and sex, educational level of both parents, child's and family history of atopic diseases, feeding method during first 6 months of life, use of kerosene as fuel, overcrowding at home (defined as more than two persons per room), pet ownership, and passive smoking at home.

Statistical analysis was performed using the chi-squared test; a $P$ value $<0.05$ was regarded as significant. 


\section{Results}

Out of 424 preschool children studied, 67 were reported to suffer recurrent wheezing episodes, giving a prevalence of wheeze in the studied population of $15.8 \%$. A higher percentage of the boys were affected more than the girls (16.4\% compared with $15.1 \%$ ), a ratio of boys to girls of $1.09: 1$ (Table 1). The percentage of wheezy children was slightly higher in the city centre $(16.3 \%)$ than in the rural area $(15.0 \%)$. In general, allergic disease in first-degree relatives was associated with recurrent wheeze among preschool children, significantly so for asthma $(44.8 \%$ among wheezy children versus $15.1 \%$ nonwheezers, $P<0.001$ ) (Table 2).

More wheezy children had been formula-fed or given supplements during the first 6 months of life than non-wheezy children ( $32.8 \%$ versus $28.9 \%$ ), but the difference was not statistically significant (Table 2). Slightly more wheezy children than nonwheezers were living in crowded families $(67.2 \%$ versus $63.3 \%)$. Other environmental factors which showed differences that were not significant were exposure to kerosene, smoking and pets.
Wheezy children had a higher percentage of parents of low educational level (none/primary) than non-wheezy children $(52.2 \%$ versus $45.9 \%$ ) (Table 2 ).

\section{Discussion}

This study of the prevalence rate of wheeze among preschool children should be viewed as being no more than descriptive. The accuracy of the results may be influenced by parental recall; however the validity of the method used is well proved and is of high repeatability $[1,9,10]$. Although there has been a controversy about the diagnosis of asthma and recurrent wheeze among preschool children, prevalence studies usually give a cumulative rate of both $[1,4,9]$. The prevalence of recurrent wheeze among preschool children in our survey $(15.8 \%)$ was very similar to that reported in a study in Britain (15.6\%) [1,9].

The observed geographical difference in the prevalence of wheeze $(15.0 \%$ in the rural area compared with $16.3 \%$ in the city centre) was not statistically significant and may have been affected by the relatively smaller sample size in the rural area. Esti-

\begin{tabular}{|c|c|c|c|c|c|c|}
\hline \multirow[t]{2}{*}{ Variable } & \multicolumn{2}{|c|}{ Wheezy children } & \multicolumn{2}{|c|}{$\begin{array}{l}\text { Non-wheezy } \\
\text { children }\end{array}$} & \multirow{2}{*}{$\begin{array}{c}\text { Total } \\
\text { No. }\end{array}$} & \multirow[t]{2}{*}{ Pvalue } \\
\hline & No. & $\%$ & No. & $\%$ & & \\
\hline \multicolumn{7}{|l|}{ Sex } \\
\hline Male & 35 & 16.4 & 178 & 83.6 & 213 & \\
\hline Female & 32 & 15.1 & 179 & 84.9 & 211 & NS \\
\hline \multicolumn{7}{|l|}{ Area } \\
\hline Rural & 24 & 15.0 & 136 & 85.0 & 160 & \\
\hline Urban & 43 & 16.3 & 221 & 83.7 & 264 & NS \\
\hline Total & 67 & 15.8 & 357 & 84.2 & 424 & \\
\hline
\end{tabular}

NS $=$ not significant .

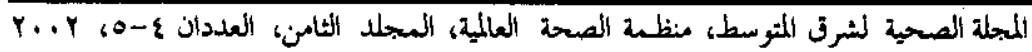




\begin{tabular}{|c|c|c|c|c|c|}
\hline \multirow[t]{2}{*}{ Risk factor } & \multicolumn{2}{|c|}{$\begin{array}{l}\text { Wheerzy children } \\
\qquad(n=67)\end{array}$} & \multicolumn{2}{|c|}{$\begin{array}{c}\text { Non-wheezy } \\
\text { children } \\
(n=357)\end{array}$} & \multirow[t]{2}{*}{ P-value } \\
\hline & No. & $\%$ & No. & $\%$ & \\
\hline \multicolumn{6}{|l|}{$\begin{array}{l}\text { Family history of } \\
\text { allergic disease }\end{array}$} \\
\hline Asthma & 30 & 44.8 & 54 & 15.1 & $P<0.001$ \\
\hline Allergic rhinitis & 22 & 32.8 & 89 & 24.9 & NS \\
\hline Other allergic disease & 6 & 9.0 & 24 & 6.7 & NS \\
\hline \multicolumn{6}{|l|}{ Breastfoeding } \\
\hline Exclusive & 45 & 67.2 & 254 & 71.1 & \\
\hline Not exclusive" & 22 & 32.8 & 103 & 28.9 & NS \\
\hline \multicolumn{6}{|l|}{ Parental education } \\
\hline Low (none/primary) & 35 & 52.2 & 164 & 45.9 & \\
\hline High (secondary/higher) & 32 & 47.8 & 193 & 54.1 & NS \\
\hline \multicolumn{6}{|l|}{ Household factors } \\
\hline Overcrowding & 45 & 67.2 & 226 & 63.3 & NS \\
\hline Smoking at home & 43 & 64.2 & 230 & 64.4 & NS \\
\hline Pet ownership & 34 & 50.7 & 167 & 46.8 & NS \\
\hline Kerosene as fuel & 50 & 74.6 & 258 & 72.3 & NS \\
\hline
\end{tabular}

mates of cumulative prevalence of wheeze in Britain have been reported to range from $11.1 \%$ to $24.7 \%$ in children, irrespective of asthma diagnosis [4]. Studies among schoolchildren show geographical variations and wheeze ranges from $23 \%$ in the United Kingdom overall (children who have ever wheezed) [11] to $9 \%$ in Saudi Arabia [12] and the Scottish highlands [13] (children who have recurrent wheezing only during the last year). The observed difference in prevalence of wheeze is a confirmation of the geographical variation of prevalence of asthma and its possible underlying environmental factors [14].
The present study did not look at the prevalence of wheeze in relation to age. Current wheezing is reported to be more common among preschool children (11.3\%) [9] than older children (14.8\%), perhaps due to a proportional increase in airway diameter with age $[4,11,15]$.

Little difference in the prevalence of wheeze was observed between boys and girls in our study, which contradicts the results of Luyt et al. and Horwood et al. who found wheeze to be more common among boys $[7,9]$.

The most important risk factor for preschool wheezing in our study was a posi- 
tive family history of asthma. This was also reported by Horwood [7] and Luyt [1]. In contrast, Martinez et al. showed an association between preschool wheeze and family history in patients with persistent wheeze but not in those who wheezed transiently during the first 3 years of life [5]. The latter group also show no association between wheeze and skin allergies or elevated IgE levels and they had underlying diminished airway function during infancy but not later $[5,16]$. Our study found that wheezy children were most likely to be asthmatic rather than having transient wheezing.

The environmental factors studied in our survey did not show a causal relationship with preschool wheezing episodes. Birth cohort studies of infants of atopic families [5,7] and controlled primary prevention trials of asthma [6] have shown contradictory results. Although statistically not significant in this study, wheeze was more common among preschool children who had been formula-fed or fed supplements in the first 6 months of life than those who had been exclusively breastfed. This may be explained by the protective effect of breastfeeding against allergic disease and respiratory tract allergies $[6,17]$. Horwood et al. [7] did not find such a protective effect, which might be related to the provision of exclusive breastfeeding and control of environmental allergens in that study.

Pet ownership, over-crowding and use of kerosene as fuel were common in the families visited, but no causal association with wheeze was found, although these factors were more common among the families of wheezy children. These indoor factors may, individually or in combination, increase the number of episodes of wheeze as some may act as allergens or irritants (kerosene, animal dander) $[1,6]$. Passive smoking in our study did not seem to be related to development of wheeze, a finding which contradicts the known association of tobacco smoke with wheezing illnesses in children [5]. However, smoking may not necessarily induce wheeze but may perpetuate wheezing episodes $[7,18]$ due to increased lower respiratory infections, the allergenic effects of smoke acting, increased bronchial hyper-responsiveness, or a combination of these $[7,18,19]$.

Wheezing illnesses were more prevalent among the children of parents with low education (none/primary) than parents with high education (secondary/university). This and additional social factors may contribute to the greater prevalence of wheeze among the children of families with lower socioeconomic status [1I].

\section{Conclusion}

We conclude that recurrent episodes of wheezing affect a high proportion of preschool children in southern Iraq. Both environmental and familial factors contribute to this. Whether these patients are truily asthmatic or suffer transient wheezing illnesses needs further follow-up studies and pulmonary function tests.

\section{References}

1. Luyt DK et al. Wheeze in preschool children and its relation with doctor diagnosed asthma. Archives of disease in childhood, 1994, 71:24-30.

2. Wilson NM. Wheezy bronchitis revisited. Archives of disease in childhood, 1989, 64:1194-9.

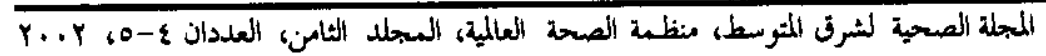


3. Sears M. Epidemiology of childhood asthma. Lancet, 1997, 350:1015-20.

4. Godfrey S. Chitdhood asthma. In: Clark TJH, Godfrey S, eds. Asthma, 2nd ed. London, Chapman and Hall, 1983:41556.

5. Martinez ED et al. Asthma and wheezing in the first six years of life. The Group Health Medical Associates. New England journal of medicine, 1995, 332(3): 133-8.

6. Chan-Yeung $M$ et al. A randomized controlled study on the effectiveness of a multifaceted intervention program in the primary prevention of asthma in highrisk infants. Archives of pediatrics and adolescent medicine, 2000, 154:65763.

7. Horwood LT, Fergusson DM, Shannon FT. Social and familial factors in the development of early childhood asthma. Pediatrics, 1985, 75(5):859-68.

8. Tabachnik E, Levision H. Infantile bronchial asthma. Journal of allergy and clinical immunology, 1981, 67(5):339-47.

9. Luyt DK, Burton P, Simpson H. An epidemiological study of wheeze, doctor diagnosed asthma and cough in preschoot children in Leicestershire. British medical journal, 1993, 306:1386-90.

10. Venables $\mathrm{KM}$ et al. Respiratory symptoms questionnaire for asthma epidemiology: Validity and reproducibility. Thorax, 1993, 48:214-9.

11. Strachen DP et al. A national survey of asthma prevalence, severity, and treat- ment in Great Britain. Archives of disease in childhood, 1994, 70:174-8.

12. Alshehri MA et al. Screening for asthma and associated risk factors among urban schoolboys in Abha City. Saudi medical joumal, 2000, 21(11):1048-53.

13. Austin B, Russel G. Wheeze, cough, atopy and indoor environment in the Scottish Highlands. Archives of disease in childhood, 1997, 76:22-6.

14. Burr ML. Childhood asthma in four countries: a comparative study. International journal of epidemiology, 1994, 23(2): 341-7.

15. Blair $H$. Natural history of childhood asthma. Archives of disease in childhood, 1977, 52:613-9.

16. Martinez ED et al. Diminished lung function as a predisposing factor for wheezing respiratory ilinesses in infants. New England journal of medicine, 1988, 319(17):1112-7.

17. Saarinen UM, Kajosaari M. Breast feeding as prophylaxis against atopic disease: prospective follow up study until 17 years old. Lancet, 1995, 346:1065-9.

18. Leeder SR et al. Influence of family factors on asthma and wheezing during first five years of life. British journal of preventive and social medicine, 1976, 30: 2138.

19. Lebowitz MD, Holberg CJ, Martinez ED. A longitudinal study of risk factor in asthma and chronic bronchitis in childhood. European journal of epidemiology, 1990, 6(4):341-7. 